\title{
THE FORMATION OF LANGUAGE COMPETENCE OF FOREIGN STUDENTS-ECONOMISTS B Y MEANS OF DISTANCE TECHNOLOGIES
}

\section{Kopylova O.V., Titarenko O.O., PhD in Philology (Kharkiv)}

The article analyzes the possibilities of using the authors' course "Foreign language" (for foreign students), certified by the E-learning center of V.N. Karazin Kharkiv National University, on teaching a language of instruction to $2^{\text {nd }}-y e a r$ foreign students of economic specialties. The relevance of the article is undeniable in the transition to a blended or full-distance learning systemin higher education.

The authors have outlined research on the issue of e-learning and distance learning, identified the most productive forms of working with foreign audiences ("Face-to-Face Driver" and "Flex"). The structure of the authors' course "Foreign language" (for foreign students), posted on the Moodle platform, and the peculiarities of its application are discussed in detail. The tasks included in the course, consisting of three sections (six topics), are aimed at developing language competence (learning grammar of complex sentences), skills of working with texts of educational-professional and socio-cultural spheres of communicative connection (specifically professional economic texts and culturological ones). The authors state that the theoretical explanations of grammatical material, audio and video fragments, a detailed glossary containing explanations of linguistic terms, unfamiliar to students, tokens and even interpretations of economic terms, presentations, various practical and individual tasks improve students' language skills and their communicative competence.

It has been proven that distance courses developed on the bas is of the Moodle platform open up many opportunities for effective work of students while leaming a foreign language within the framework of a blended learning system.

Key words: distance course, distance leaming, blended learning, foreign students, language of a specialty, Moodle platform.

Копилова О.В., Тітаренко О.О. Формування мовної компетенції іноземних студентів економічного профілю засобами дистанційних технологій. У статті проаналізовано можливості застосування авторського курсу «Іноземна мова» (для іноземних студентів), сертифікованого Центром електронного навчання Харківського національного університету імені В.Н. Каразіна, у викладанні мови навчання студентам-іноземцям 2 курсу економічних спеціальностей. Актуальність статті $є$ беззаперечною в умовах переходу на змішану чи повністю дистанційну систему навчання у закладах вищоїосвіти.

Авторами окреслено коло дослідників питань електронного та дистанційного навчання, виділено найбільш продуктивні форми роботи (C) Kopylova O.V., Titarenko O.O., 2021 
3 іншомовною аудиторією («Face-to-Face Driver» та «Flex»). Детально висвітлено структуру авторського курсу «Іноземна мова» (для іноземних студентів), розміщеного на платформі Moodle, та особливості його застосування. Завдання, розміщені у курсі, що складається 3 трьох розділів (шести тем), націлені на розвиток мовної компетенції (вивчення граматики складнопідрядного речення), навичок роботи 3 текстами навчальнопрофесійної та соціально-культурної сфер комунікативного підключення (професійними економічними текстами та культурологічними). Зазначено, що наявні у курсі теоретичні пояснення граматичного матеріалу, аудіо - та відеофрагменти, детальний глосарій, що містить пояснення лінгвістичних термінів, незнайомих студентам лексем та тлумачення економічних термінів, презентації, різноманітні практичні та індивідуальні завдання підвищують рівень знань мови навчання студентів та їхню комунікативну компетентність.

Доведено, що дистанційні курси, розроблені на базі платформи Moodle, відкривають багато можливостей для результативної роботи студентів під час вивчення іноземноїмовив умовах змішаноїформи навчання.

Ключові слова: дистанційне навчання, дистанційний курс, змішане навчання, іноземні студенти, мова спеціальності, платформа Moodle.

Копылова Е.В., Титаренко Е.А. Формирование языковой компетенции иностранных студентов экономического профиля средствами дистанционных технологий. В статье проанализированы возможности применения авторского курса «Иностранный языю» (для иностранных студентов), сертифицированного Центром электронного обучения Харьковского национального университета имени В.Н. Каразина, в преподавании языка обучения студентам-иностранцам 2 курса экономических специальностей. Актуальность статьи является бесспорной в условиях перехода на смешанную или полностью дистанционную форму обучения в учреждениях высшего образования.

Авторами очерчен круг исследователей вопросов электронного и дистанционного обучения, выделены наиболее продуктивные формы работы с иноязычной аудиторией («Face-to-Face Driver» и «Flex»). Подробно освещена структура авторского курса «Иностранный языю» (для иностранных студентов), размещенного на платформе Moodle, и особенности его применения. Задания, размещенные в курсе, состоящем из трех разделов (шести тем), нацелены на развитие языковой компетенции (изучение грамматики сложноподчиненного предложения), навыков работы с текстами учебно-профессиональной и социально-культурной сфер коммуникативного подключения (профессиональными экономическими текстами и культурологическими). Отмечено, что имеющиеся в курсе теоретические объяснения грамматического материала, аудио- и видеофрагменты, подробный глоссарий, содержащий объяснение лингвистических терминов, незнакомых студентам лексем и толкование экономических терминов, презентации, различные практические и индивидуальные задания повышают уровень знания языка обучения студентов и их коммуникативную компетентность. 
Доказано, что дистанционные курсы, разработанные на базе платформы Moodle, открывают множество возможностей для результативной работы студентов во время изучения иностранного языка в условиях смешанной формы обучения.

Ключевые слова: дистанционный курс, дистанционное обучение, иностранные студенты, платформа Moodle, смешанное обучение, язык специальности.

Problem statement. Modernization of the Ukrainian educational space that is carried out in the context of technological innovations of the world educational system based on intercultural and interdisciplinary integration, digitalization of an educational process, implementation of competency approach requires an understanding of the growing role of e-learning that has become one of the priority tasks of modern domestic pedagogical science. The introduction of distance learning is one of the ways to modernize higher education in Ukraine in the context of globalization and intensive development of information technology, especially in the context of quarantine restrictions associated with the spreading of COVID-19. Presently, distance technologies are widely used in almost all areas of education, including the teaching of a non-native language to foreign speakers.

Creating an effective learning system based on information technology is an urgent task for all levels of education. One of the systems focused on the professional development of future professionals is a system of teaching foreign language students using information technology.

Considering the constant growth of educational information flow, the formation of students' ability to learn independently and to navigate in the information stream is especially important. Therefore, modern pedagogical technologies of distance, e-learning, and blended learning, which are designed to implement a personality-oriented approach to training and aimed at developing individual resources of students, are becoming especially relevant. The choice of the optimal ratio of the traditional educational system, modern pedagogical innovations, and tools of information and communication technologies, issues of information and methodological support of distance learning, as well as its application at different educational levels are important problems of introducing innovative forms of learning, including foreign language training. This determines the rele vance of the proposed study. 
The aim of the article is to analyze the possibilities of using the elements of the authors' distance course "Foreign language" (for foreign students) in the process of teaching $2^{\text {nd }}$-year foreign students of economic specialties.

Analysis of current research shows that distance learning as a form of organization of the educational process has been studied by many foreign researchers (T. Anderson, J. Boat, V. Bykov, F. Vedemeyer, D. Harrison, J. Daniel, R. Delling, V. Zhulkevskaya, S. Kalashnikova, M. Karpenko, D. Kihan, S. Kudryavtseva, M. Moore, O. Peters, E. Polat, N. Sirotenko, K. Smith, P. Stefanenko, V. Tikhomirov, O. Khmel, A. Khutorsky, R. Holmberg and others), as well as domestic scholars (A. Anisimov, O. Kolontaevsky, V. Levchuk, A. Tymchenko, V. Oliynyk, V. Kukharenko, O. Rybalko, N. Sirotenko, B. Shunevych and other). Problems of distance learning of a foreign language, in particular Russian, were studied by E. Azimov, M. Bovtenko, A. Bogomolov, M. Bukharkina, N. Ushakova, I. Kushnir, S. Varava, N. Galskova, L. Geikhman, G. Kedrova, O. Kryukova, S. Volkov, I. Petrov, and others. Despite some differences in wording, according to scientists, the process of distance learning should be individually oriented and based on modern information technology, methods of mathematical modeling. It is noteworthy that many authors identify distance learning with e-learning (O. Artykbayeva, T. Anderson, O. Andreev, D. Harrison, N. Dubova, D. Morrison, M. Rosemberg, A. Solovov, and others).

We share the point of view of the scholars, who consider e-learning to be training, means, and methods of which provide for the use of educational information resources in electronic (digital) formats and consider distance learning to be a marginal case of e-learning, which does not contain elements of traditional learning in terms of the organization of the educational process and the interaction of its subjects with educational resources and among themselves [9].

Presentation of the main material. The possibilities of organizing the educational process are not limited to traditional and distance learning. There is a significant educational sector in which distance learning cannot be fully applied but some elements of e-learning (in particular, distance learning technologies) can be used. This applies to full-time and extramural ( $1^{\text {st }}-2^{\text {nd }}$ years $)$ forms of higher education.

Recently, the only possible form of work with students is blended learning as a more advanced model of the organization of the 
educational process, which uses the advantages of distance learning and compensates for its shortcomings. The term "blended learning" refers to a learning process that utilizes a variety of learning management techniques, such as classroom learning, asynchronous distance learning, and synchronous distance learning. "The transition to communication networks and the requirement of individualization are best coordinated in encouraging participants to create personalized distance learning scenarios, both in the synchronous and asynchronous format" (our translation - O.K., O.T.) [2: 25].

The educational process is based on the student's interaction not only with the computer but also with the teacher in active face-to-face and distance forms, when the studied program material of the discipline is summarized, analyzed, and used to solve problems. K. Buhaichuk, O. Zhelnova, I. Ippolitova, Y. Kapustin, D. Clark, V. Kukharenko, O. Rafalska, I. Semenova J. Sikora, A. Solovov, B. Starychenko, E. Tykhomyrova, V. Fandey, A. Fomina, and others have devoted their works to the problem of using blended learning in the education system, including teaching a foreign language.

V. Kukharenko defines blended learning as a purposeful process of acquiring knowledge, skills, and abilities in terms of integration of classroom and extracurricular educational activities of educational subjects based on the use and complementarity of traditional, electronic, distance, and mobile learning technologies in the presence of student self-control over time, place, routes and pace of learning [4]. To our mind, the definition of blended learning as a combination of traditional learning with learning through Internet resources, which allows carrying out a joint activity of participants of the educational process, is the most accurate one [9]. Mixed approaches to learning, including foreign language learning, have proven to be one of the most popular technologies today, as they allow taking advantage of the flexibility and convenience of distance learning and the benefits of the traditional learning system [5].

To improve the organization of the educational process of language training of foreign students, we consider it appropriate to use the materials of distance courses in models of blended learning.

Among the models of blended learning identified by the researchers [8], in our opinion, the most effective for teaching a foreign language to full-time second-year foreign students-economists is the 'Face-to-Face Driver' model, which gives more flexibility in combining traditional 
methods with e-learning in the organization of practical classes. This model involves studying the main part of the curriculum in the classroom during direct interaction with the teacher, and e-learning is used as a supplement to the main program (work with electronic resources is organized on computers during the lesson).

When integrating the model into the traditional educational process of teaching foreigners, we consider it appropriate to use our distance learning course with a predominant in-class component $(30 \%-40 \%$ of information and communication technologies (ICT) in the course), because the degree of independence of students during the acquisition of the educational material of the discipline in the initial courses is not very high. It is expected to use the distance course developed on the Moodle platform to improve practical skills of working with economic texts and grammar material provided by the teacher in the classroom, to develop skills of working with audio and video materials (listening), for self-assessment and self-improvement (it should be noted that all the work, including independent, is checked by the teacher and commented for each student individually). The final control takes place in the classroom under the control of the teacher.

For small full-time groups with a reduced number of classroom hours and extramural foreign students, we consider it appropriate to introduce a model of blended learning "Flex", in which most of the foreign language curriculum is learned in e-learning, the teacher accompanies students remotely to go over complex questions and organizes classroom classes as consultations. The final test is also taken in the classroom under the control of the teacher.

It is known that the educational and professional sphere of communicative connection is the leading one in the practice of teaching Russian/ Ukrainian to foreign students of non-language specialties, in particular to students of economic profile. Language for such students is a tool for obtaining a specialty and an educational discipline, with help of which the knowledge in economics is acquired. A language of instruction provides students with linguistic means for solving communicative tasks in the educational and professional sphere of communication. According to O. Mitrofanova, the content and communicative competence of non-philological students is based on mastering the procedures and skills of extracting and structuring knowledge in the process of acquiring a specialty [5]. A language is a tool for achieving such goals. The complex content of the educational 
and professional sphere of communicative connection in teaching a language to foreign students of economic specialties consists of the following components:

1) mastering the necessary linguistic means, specific to this language subsystem;

2) formation and development of skills and abilities in the main areas of speech activity: speaking, reading, listening, and writing, which are necessary for students for professional communication;

3) mastering the established minimum of basic information of meaningful nature, relevant to economic specialties.

It should be emphasized that the first two components are the purpose of work on the language for the specialty, and the third component is the content of special texts, based on which the study of the language for the specialty is carried out [7].

The content of language classes is based on material that is selected taking into account the communicative needs of students-economists: to acquire knowledge, skills, and abilities sufficient and necessary to understand the major subjects in the second year. For studentseconomists, the study of the language for the specialty is organized based on the language material of the economic theory course (microeconomics and macroeconomics), which is a major subject in the $1^{\text {st }}$ and $2^{\text {nd }}$ years at the university.

The text material of the course "Foreign language" (for foreign students) corresponds to the topics studied in the courses of major subjects. The educational text is the highest unit for observation and comprehension of the lexical and grammatical material studied, therefore such texts are saturated with special lexical units-terms and grammatical constructions studied by foreign students at this stage of training. In addition, the text is the basis for the formation of certain language skills and is a source of relevant special information, motivating the language activities of students, which determines the cognitive and problematic nature of such texts.

The practice of working in a foreign audience shows that foreign students have significant difficulties in learning at all stages of forming a foreign specialist (including training at the preparatory faculty), and the main difficulty is to master a language of specialization in the educational and professional field of connection within the framework of education program. In recent years, the main contingent of fore igners choosing economic specialties are citizens of the CIS countries 
who have not studied at preparatory faculties and have a low level of language training. Therefore, the level of students' understanding of specialized texts at the beginning of the main stage is insufficient to ensure successful learning process of second-year economics students, and communicative situations of the educational process require the student-economist to navigate in texts of special literature and textbooks, to listen and understand lectures, as well as the ability to produce their unprepared utterance in the professional sphere.

The communicative nature of the activities of students and language teachers in class supports the high motivation of foreign students to learn the language because they see it as a tool for mastering academic disciplines within their chosen specialty. Grammatical material is the basis for the formation of speech skills to extract information from a text (and further to create their texts), and it reveals the patterns of functioning of the studied language means. Teaching the language of the specialty is teaching not only special vocabulary but also the linguistic system of functional style (scientific style constructions are studied).

The use of additional interactive learning resources, which can be accessed in the Moodle system, will contribute to the intens ification of the educational process and the formation of foreign studentseconomists' professional competence. In our case, the use of elements of distance learning, built in the Moodle system, will organize effectively the process of language training of foreign students, implement ideas of individual approach in the learning process, enhance the cognitive activity of students, and involve them in independent work.

When developing the distance course "Foreign language" (for foreign students), we used standard elements that meet the requirements of creating a distance course [1].

The structure of the distance course contains a thematic plan of practical classes with the division of time in hours into practical classes and independent work. Lectures are not foreseen in the curriculum of the discipline. The course includes an annotation of the discipline, curriculum, guidelines for studying the discipline, a scenario of interaction between a teacher and students, theoretical material, tasks for practical and test works, questions for self-control, exam questions, glossary (vocabulary of basic terms and concepts), a list of literature references recommended for students, guidelines for studying the sections, a transparent scheme of scoring. 
The course consists of 6 topics, included in 3 sections. Two topics of the first section are devoted to the study of the grammar of a complex sentence. Before each practical task, extensive theoretical explanations are given with examples and questions for self-control. A student who has missed a lesson or wants to revise the material has the opportunity to work on it independently. The theory is accompanied by presentations that facilitate the process of perception of new information and maintain interest in the material. There are test questions at the end of each topic, which are selected by the program individually for each student from the general database of questions. Test completion time is limited. The works done by students are commented on by the teacher.

Two topics of the second section are devoted to working with texts of the educational and professional sphere of communicative connection. When organizing the process of teaching language to foreign students, we assume that the main unit of study (a typical text) is the basis for creating a set of tasks aimed at developing various skills, helping to teach the correct construction of thought, not just forms of its expression. A student receives an additional block of information in the form of tables, structural and semantic schemes, samples needed to analyze the semantic, communicative, and structural integrity of the text. A special system of tasks develops students' skills to produce and finalize communicatively integral texts independently.

Each block of tasks involves working out a certain set of operations with language and informative material of the text. Texts related to the student's specialty are used for the work. Thus, the student gradually learns the material, i.e. receives a set of certain know ledge and acquires skills and abilities to work independently with the text that contributes to the activation of students' mental activity in mastering the language of the specialty.

Each text (four in total) has pre-text and post-text tasks. Students analyze new words, develop skills in working with word forms, learn to make a plan of the text (nominal and interrogative), make a short written translation of the main information, prepare for oral translation, and produce their thoughts on the topic. These sections also contain audio texts accompanied by a video series with keywords. Listening tasks, which should correspond to interactivity, multimedia, and nonlinearity [10], are especially important for learning a foreign language. 
The last two topics of the third section develop skills of working with texts of the socio-cultural sphere of communicative connection. They are devoted to the study of the peculiarities of the Ukrainian culture and the culture of the student's country and contribute to the deepening of students' linguistic and cultural knowledge. The first topic involves acquaintance with the traditions of the Ukrainian people. Texts are accompanied by a large amount of illustrative material, presentations, audio, and video materials. The glossary (hints with the interpretation of new words) and hyperlinks to third-party Internet services are especially important in this section. After getting acquainted with all the materials, students are asked to check the level of knowledge acquisition by completing test tasks and writing a short text about the calendar-household and family-ritual traditions of the Ukrainian people.

The second topic of the third section is devoted to the study of the culture of a student's nation. Each student prepares a story about the traditions of their country and a presentation.

Students, who want to improve the ir grades, will be granted access to an individual additional task at the end of the course. Individual tasks are of different levels - from the preparation of abstracts on the topic being studied, to writing an article for publication in a collection of student work and to making a report at a conference.

Also, every week at the time determined by the teacher during the semester, students receive individual consultations in the "Chat" mode.

Conclusions. We consider it expedient to use elements of distance learning in the training course "Foreign language" (for foreign students) for $2^{\text {nd }}$-year students-economists. In our opinion, the practical application of this course opens the possibility of implementing the tasks assigned to foreign students in the process of obtaining know ledge in the specialty in the educational and professional sphere of communicative connection.

Distance technologies effectively complement, develop and expand traditional forms of lessons. With their help, students have constant access to educational material, and the teacher can test knowledge, advise students, exchange materials and tasks. The advantages of using distance learning as a support for traditional classes are obvious because they enable the teacher to dynamically switch students from frontal to individual work with materials from various electronic resources. 
Prospects of further research are a more detailed study of the features of distance learning courses, theory, and practice of their application in teaching a language of instruction to foreign students.

\section{LITERATURE}

1. Вимоги до структури дистанційного курсу, затверджені рішенням Координаційної ради $з$ питань електронного (дистанційного) навчання Харківського національного університету імені В.Н. Каразіна від 08.10.2013 p. Протокол № 2. dist.karazin.ua/moodle/cource/ URL: http://dist.karazin.ua/moodle/cource (дата звернення: 10.02.21).

2. Волков С.О. Навчення як модифікована форма індивідуального досвіду та його місце у дистанційній освіті. Викладання мов у вищих навчальних закладах освіти на сучасному етапі. Межпредметні зв'язки. Харків: ХНУ імені В.Н. Каразіна, 2021. Вип. 37. С. 23-35. DOI: https://doi.org/10.26565/2073-4379-2020-37-02.

3. Копылова Е.В., Курилюк Т.И., Санина Л.П. Читаем тексты по экономике: учебное пособие для иностранных студентов. Х.: ХНУ имени В.Н. Каразина, 2011. 124 с.

4. Кухаренко B.M. Змішане навчання. Вебінар. URL: http://www.wiziq.co m/online-class/2190095-intel-blended (дата звернення: 10.02.21).

5. Кухаренко В.М., Березенська С.М., Бугайчук К.Л., Олійник Н.Ю. та інші. Теорія та практика змішаного навчання: монографія / за ред. В.М. Кухаренка. Харків: «Міськдрук», НТУ «ХПІ», 2016. 284 с.

6. Митрофанова О.Д. Научный стиль речи: проблемы обучения. М.: Рус. яз., $1985.128 \mathrm{c}$.

7. Погорельская Л.И. Особенности научного текста в учебном пособии по языку специальности. Русский язык и литература в пространстве мировой культуры: Материалы ХІІІ Конгресса МАПРЯЛ, г. Гранада, Испания, 13-20 сентября 2015. Том 10. С. 830-834.

8. Сікора Я. Реалізація змішаного навчання у вищому навчальному закладі. Науковий вісник Ужгородського національного університету. Серія: Педагогіка, Соціальна робота. 2016 . Вип. 2. С. 236-239.

9. Стариченко Б.Е., Семенова И.Н., Слепухин А.В. О соотношении понятий електронного обучения в высшей школе. Образование $u$ наука. 2014. № 9. С. 51-68.

10. Ушакова Н.В. Проблеми навчання іноземних студентів аудіювання засобами інформаційно-комунікаційних технологій. Викладання мов у вищих навчальних закладах освіти на сучасному етапі. Межпредметні зв'язки. Харків: ХНУ імені В.Н. Каразіна, 2018. Вип. 33. С. 89-102. DOI: https://doi.org/10.26565/2073-4379-2018-33-08. 


\section{REFERENCES}

1. Vymohy do struktury dystantsiinoho kursu, zatverdzheni rishenniam Koordynatsiinoi rady z pytan elektronnoho (dystantsiinoho) navchannia Kharkivskoho natsionalnoho universytety imeni V.N. Karazina vid 08.10.2013 r. Protokol № 2 [Requirements for the distance course approved by the Coordinating Council for electronic (distance) training Kharkiv National University V.N. Karazin of 08.10.2013. Minutes number 2]. dist.karazin.ua/moodle/courcel. Available at: http://dist.karazin.ua/moodle/cource [Accessed 20 Feb. 2019] [in Ukrainian].

2. Volkov S.O. (2021). Learning as a modified form of individual experience and its place in distance education. Vykladannia mov $u$ vyshchykh navchalnykh zakladakh osvity na suchasnomu etapi. Mizhpredmetni zviazky [Teaching Languages at Higher Institutions]. Kharkiv: V.N. Karazin Kharkiv National University, 37, pp. 23-35 [in Ukrainian]. DOI: https://doi.org/10.26565/2073-4379-2020-37-02.

3. Kopylova, E.V., Kuriljuk, T.I. and Sanina, L.P. (2011). Chitaem teksty po ekonomike [We read texts on economics]. Kharkiv: V.N. Karazin Kharkiv National University [in Russian].

4. Kuharenko, V.M. Zmishane navchannya. Vebinar. [Mixed learning. Webinar]. Available at: http://www.wiziq.co m/online-class/2190095-intelblended [Accessed 20 Feb. 2019] [in Ukrainian].

5. Kuharenko, V.M., Berezenska, S.M., Bugajchuk, K.L. , Olijnyk, N.Yu. at al. (2016). Teoriya ta praktyka zmishanogo navchannya [Theory and practice of blended learning]. Kuharenko, V.M. (Ed.). Kharkiv: «Miskdruk», NTU «HPI» [in Ukrainian].

6. Mitrofanova, O.D. (1985). Nauchnyj stil rechi: problemy obuchenija [Scientific style of speech: learning problems]. Moscow: Russkij jazyk [in Russian].

7. Pogorelskaja, L.I. (2015). Osobennosti nauchnogo teksta v uchebnom posobii po jazyku specialnosti [Features of the scientific text in the textbook on the specialty language]. In: XIII Kongress MAPRJAL "Russkij jazyk i literatura v prostranstve mirovoj kultury" [The Thirteenth Congress MAPRYAL "Russian language and literature in the space of the world culture"]. Granada, Ispanija, 10, pp. 830-834 [in Russian].

8. Sikora, Ya. (2016). Realizaciya zmishanogo navchannya u vyshhomu navchalnomu zakladi [The implementation of the blended learning in a higher educational institution]. Naukovyj visnyk Uzhgorodskogo nacionalnogo universytetu [Scientific herald of Uzhgorod National University].Uzhgorod, 2, pp. 236-239 [in Ukrainian].

9. Starichenko, B.E., Semenova, I.N. and Slepuhin, A.V. (2014). O sootnoshenii ponjatij elektronnogo obuchenija v vysshej shkole [On the 
relationship between the concepts of e-learning in higher education]. Obrazovanie i nauka [Education and science], 9, pp. 51-68 [in Russian]. 10. Ushakova N.V. (2018). The problems of training listening skills of foreign students by information and communication technologies. Vykladannia mov u vyshchykh navchalnykh zakladakh osvity na suchasnomu etapi. Mizhpredmetni zviazky [Teaching Languages at Higher Institutions]. Kharkiv: V.N. Karazin Kharkiv National University, 33, pp.89-102 [in Ukrainian]. DOI: https://doi.org/10.26565/2073-4379-2018-33-08.

Копилова Олена Володимирівна, старший викладач кафедри мовної підготовки 1 Навчально-наукового інституту міжнародної освіти Харківського національного університету імені В.Н. Каразіна (61022, Україна, Харків, майдан Свободи, 4); e-mail: elene_k@i.ua; orcid: http://orcid.org/0000-0001-8040-6825.

Копылова Елена Владимировна, старший кафедри преподаватель кафедры языковой подготовки 1 Учебно-научного института международного образования Харьковского национально го университета имени В.Н. Каразина (61022, Украина, Харьков, пл. Свободы, 4); e-mail: elene_k@i.ua; orcid: http://orcid.org/0000-0001-8040-6825.

Olena Kopylova, Language Training Department 1, Assistant Professor, Language Training Department 1, International Education Institute for Study and Research, V.N. Karazin Kharkiv National University (61022, Kharkiv, 4 Svoboda Square); e-mail: elene_k@i.ua; orcid: http://orcid.org/0000-00018040-6825.

Тітаренко Олена Олексіївна, канд. філол. наук, старший викладач кафедри мовної підготовки 1 Навчально-наукового інституту міжнародної освіти Харківського національного університету імені В.Н. Каразіна (61022, Україна, Харків, майдан Свободи, 4); e-mail: olena.titarenko@karazin.ua; orcid: https://orcid.org/0000-0003-1425-1698.

Титаренко Елена Алексеевна, канд. филол. наук, старший преподаватель кафедры языковой подготовки 1 Учебно-научного института международного образования Харьковского национального университета имени В.Н. Каразина (61022, Украина, Харьков, пл. Свободы, 4); e-mail: olena.titarenko@karazin.ua; orcid: https://orcid.org/0000-0003-1425-1698.

Olena Titarenko, PhD in Philology, Assistant Professor, Language Training Department 1, International Education Institute for Study and Research, V.N. Karazin Kharkiv National University (61022, Kharkiv, 4 Svoboda Square); e-mail: olena.titarenko@ karazin.ua; orcid: https://orcid.org/00000003-1425-1698. 